\title{
Ossetian Language
}

National Cancer Institute

\section{Source}

National Cancer Institute. Ossetian Language. NCI Thesaurus. Code C154072.

An Eastern Iranian language spoken in the Ossetia region of Russia. 